\title{
10
}

\section{Paleoenvironment of Lapita sites on Fanga 'Uta Lagoon, Tongatapu, Kingdom of Tonga}

William R. Dickinson

Department of Geosciences, University of Arizona, Tucson, Arizona 85721, USA

wrdickin@dakotacom.net

\section{Introduction}

The density of Lapita archaeological sites surrounding Fanga 'Uta Lagoon indenting the north coast of Tongatapu is the greatest in Tonga. On average, at least one site is known per $2.5 \mathrm{~km}$ of reconstructed curvilinear paleoshoreline and many additional sites probably remain to be discovered. All the sites give the archaeological impression of having been coastal habitations, but most lie now at the seaward edge of the flat tephra-covered surface of interior Tongatapu along a slope declivity marking the position of an emergent mid-Holocene paleoshoreline that stands varying distances inland from beaches and mangrove thickets along the present lagoonal shoreline. To understand the original paleoenvironmental setting of the Lapita sites, the mid-Holocene paleoshoreline of Fanga 'Uta Lagoon associated with a hydro-isostatic highstand in tropical Pacific sea level was traced in as much detail as recent urban and agricultural modification of the Tongatapu landscape allows.

Lapita sites in the varied island groups of the southwest Pacific were occupied thousands of years ago when nearly all local coastal environments were different than today. Paleoenvironmental change at archaeological sites on Pacific island coasts has been affected by multiple influences including tectonic uplift or subsidence of individual islands or island clusters (Dickinson 2001; Dickinson and Green 1998), the spread of lava flows or blankets of volcanic ash over islands near eruptive centers (Green 2002; Green and Anson 2000; Torrence et al. 2000), enhanced sedimentation that was triggered by accelerated erosion of slopes in island interiors in response to deforestation that accompanied expanding human impact on inland vegetation (Anderson et al. 2006; Clark and Michlovic 1996; Dickinson et al. 1998), the accretion of beach ridges to form 
enlarged coastal strands (Dickinson and Burley 2007; Kirch 1998, 1993; Kirch et al. 1990), and drawdown in local sea level following the regional mid-Holocene hydro-isostatic highstand in tropical Pacific sea level (Dickinson 2001).

Drawdown in sea level from the mid-Holocene highstand has had the most general and ubiquitous impact on coastal Lapita sites, and has been the dominant impact where other influences on relative sea level are absent or minimal. The Lapita sites surrounding Fanga 'Uta Lagoon illustrate especially well the effect of hydro-isostatic change in sea level on coastal Lapita sites because neither uplift nor subsidence has affected Tongatapu since Lapita occupation, post-Lapita tephra falls have not been detected, surface streams transporting sediment are virtually non-existent on Tongatapu, and surf action required to expand coastal beaches and spits is restricted to passages near the mouths of the lagoon. In effect, the setting of Fanga 'Uta Lagoon isolates hydro-isostatic effects to the near exclusion of other effects on coastal environments.

\section{Highstand-Lapita relations}

Isotopic dating of emergent mid-Holocene reef flats on Tongatapu by combined uranium-series and radiocarbon methods suggest that the mid-Holocene hydro-isostatic highstand of regional sea level in Tonga peaked at some time during the interval 4800-3600 BCE with appropriate analytical uncertainties taken into account (Dickinson et al. 1999; Taylor 1978; Taylor and Bloom 1977; Spenneman 1997). Supportive radiocarbon ages in the calibrated range of 4000-3400 BCE have been obtained from calcarenitic sands that directly overlie emergent mid-Holocene reef limestone in seacliffs near Kolonga on northeast Tongatapu (Nunn and Finau 1995), and from the base of marine mid-Holocene bay deposits sandwiched between mangrove peat layers beneath the west arm of Fanga 'Uta Lagoon southwest of Folaha (Ellison 1989). Theoretical global calculations of post-glacial hydro-isostatic effects in the tropical Pacific Ocean imply a peak highstand between 2000 BCE (Mitrovica and Peltier 1991) and 3000 BCE (Mitrovica and Milne 2002). Provisional reconciliation of the empirical and theoretical estimates for highstand timing indicates an approximate date of $3000 \mathrm{BCE}$ for the end of the peak mid-Holocene highstand in Tonga.

Excavated Lapita horizons within Tonga date generally to the interval 850-650 BCE (Burley 1998; Burley et al. 1999, 2001), distinctly later than the peak of the mid-Holocene highstand. Slightly older dates (900875 BCE) for the basal cultural horizon at Nukuleka (Figure 1), thought to be the founding Lapita settlement in Tonga (Burley and Dickinson 2001), are not significantly older. As the rate of post-mid-Holocene drawdown in regional sea level is uncertain, the exact position of local relative sea level on Tongatapu at the time of initial Lapita occupation cannot be retrodicted with full confidence. Analysis of shoreline evolution in Australia suggests, however, that the post-highstand decline in Pacific hydro-isostatic sea level was gradual, monotonic, and linear (Chappell 1983; Harvey et al. 1999; Woodroffe et al. 2000). With that assumption, relative sea level on Tongatapu at Lapita time can be hindcast closely.

Elevations of emergent mid-Holocene paleoreef flats on the leeward coast and of coeval paleoshoreline notches on the windward coast jointly document post-mid-Holocene hydro-isostatic emergence of Tongatapu (Dickinson and Burley 2007; Dickinson et al. 1999). Remnants of emergent paleoreef-flat limestone in downtown Nuku'alofa stand 2.2 above modern reef flats rising to low-tide level, and paleoshoreline notches stand $2.3 \pm 0.4 \mathrm{~m}$ ( $\mathrm{n}=8$ sites, range 1.8-2.8 m) above modern shoreline notches incised at high-tide level. More voluminous data of Nunn and Finau (1995) measured from the same assemblage of paleoshoreline notches provides an independent coordinate estimate of $2.2 \pm 0.4 \mathrm{~m}(\mathrm{n}=16$ sites, range 1.6-2.9 m) for island emergence.

The indicated emergence is in close accord with the theoretical estimate $(2.1-2.6 \mathrm{~m})$ of the magnitude of the mid-Holocene hydro-isostatic highstand in tropical Pacific sea level in Tonga derived from global calculations (Mitrovica and Peltier 1991: Fig. 8i-k). 


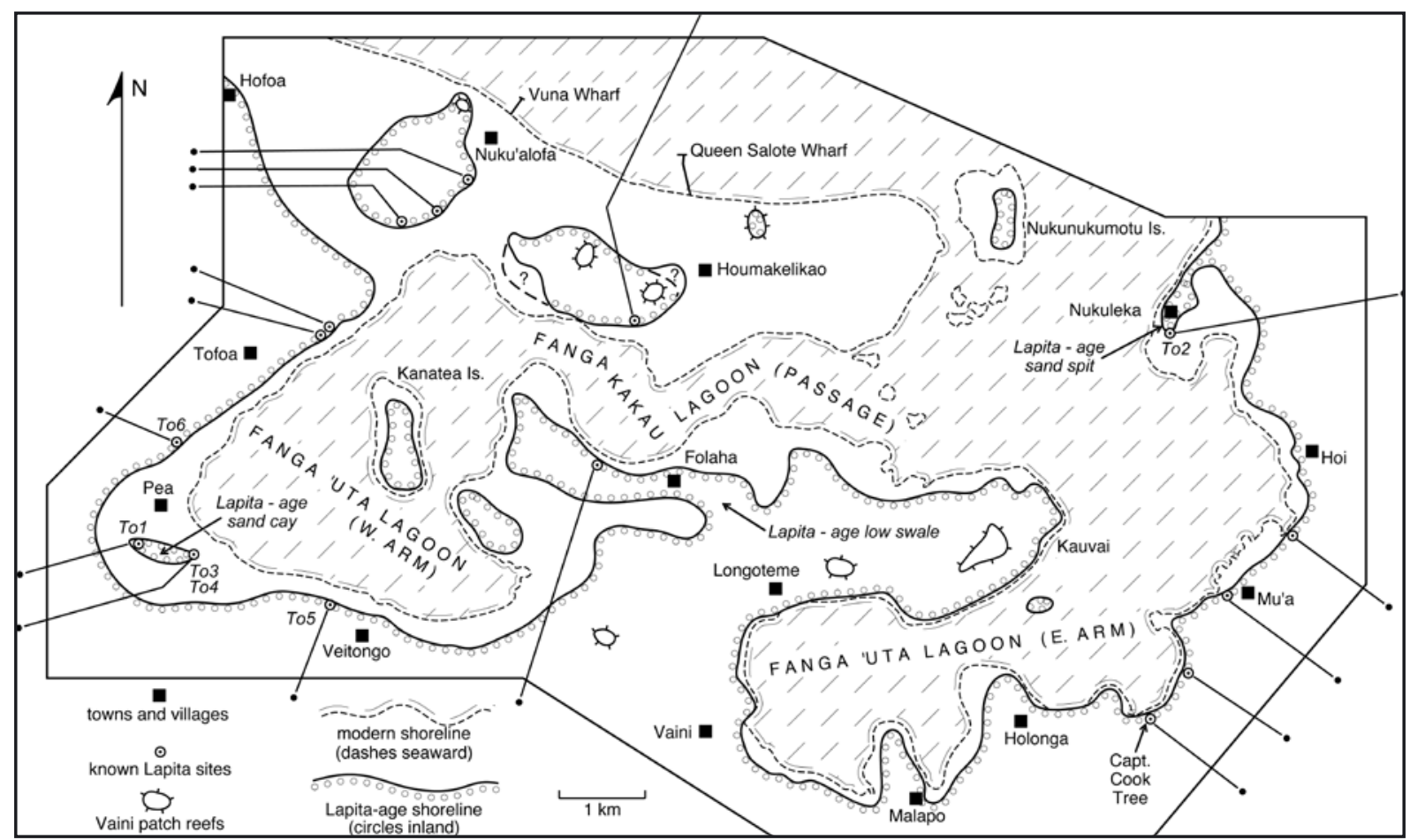

Figure 1. Modern shoreline and Lapita paleoshoreline of Fanga 'Uta Lagoon, Tongatapu, Tonga. To1-To6 Lapita sites are designations of Poulsen (1987).

Interpretations of paleoshoreline features that postulate significant Holocene tectonic deformation of Tongatapu (Ellison 1989; Nunn and Finau 1995) are discounted here because last-interglacial ( 125 ka) paleoshoreline features stand at an elevation of $6.7 \mathrm{~m}$ above modern counterparts (Dickinson and Burley 2007; Dickinson et al 1999; Taylor 1978; Taylor and Bloom 1977; Spenneman 1997; Woodroffe 1988). This observed elevation is coordinate, without tectonic uplift, with the inferred magnitude of $6 \pm 1 \mathrm{~m}$ (Dickinson 2001; Israelson and Wohlfarth 1999) for the last-interglacial eustatic highstand in global sea level. As noted below, the consistent elevation of the mid-Holocene paleoshoreline surrounding Fang 'Uta Lagoon, which penetrates deep into Tongatapu, precludes significant late Holocene tilt of the island.

In the cove west of Keleti Beach on the windward coast $3 \mathrm{~km}$ from the head of the west arm of Fanga 'Uta Lagoon, the difference in elevation between a well preserved mid-Holocene paleonotch and the active shoreline notch, developed at modern high-tide level, was scaled directly as $2.6 \mathrm{~m}$. Combining this observation with data on the emergence of mid-Holocene coral heads in Nuku' alofa on the north flank of Fanga 'Uta Lagoon, post-mid-Holocene emergence of the lagoon by $2.2-2.6 \mathrm{~m}$ is inferred. From highstand-Lapita age relations, post-Lapita emergence can be calculated as 1.2-1.4 m. Given the tidal range of 1.0-1.2 $\mathrm{m}$ for Tongatapu, this estimate of post-Lapita emergence implies that high-tide level during Lapita time had not dropped below the level of paleoreef flats constructed upward to low-tide level during the mid-Holocene highstand. At high tide during Lapita time, seawater swept as far inland, in relation to modern geography, as the older pre-Lapita paleoshoreline. In effect, the edge of dry land had not shifted seaward from the mid-Holocene paleoshoreline at Lapita time, except where buildup of sand cays or spits above gradually shoaling mid-Holocene paleoreef flats had created patches of dry land at sites that had previously been fully submerged. 


\section{Fanga 'Uta Geomorphology}

The present island of Tongatapu was formed by Pleistocene ( $>250 \mathrm{ka}$ ) uplift of the Vaini paleoreef complex developed along the crest of the forearc Tonga platform (Dickinson and Burley 2007; Dickinson et al. 1999; Roy 1990, 1997). A Vaini paleoisland, now forming the highest topography at the southeast tip of Tongatapu, was flanked by barrier reefs that have been uplifted to form the high ridges extending parallel to the eastern and southern coasts of Tongatapu. The interior lowlands of Tongatapu represent the emergent floor of the Vaini paleolagoon, which was tilted gently northward at $0.05^{\circ}-0.15^{\circ}$ during uplift (Roy 1990, 1997; Taylor 1978). Multiple isolated hills (many now being quarried for limestone) which rise from the lowlying paleolagoon floor represent ancestral patch reefs of the Vaini paleoreef complex (Dickinson and Burley 2007; Dickinson et al. 1999; Lewis et al. 1997). In a broad context, the modern Fanga 'Uta Lagoon is an undrained remnant of the Vaini paleolagoon.

In detail, however, the shoreline of Fanga 'Uta Lagoon has been modified by post-uplift and post-tilt coastal processes during late Pleistocene ( $<125 \mathrm{ka})$ and Holocene time: (1) post-uplift and post-tilt erosion, largely by coastal corrosion of exposed limestone, has incised low seacliffs into pre-Holocene limestone; (2) fringing reefs of last-interglacial $(\sim 125 \mathrm{ka})$ and mid-Holocene $(\sim 5 \mathrm{ka})$ age have been accreted to the older limestone core of Tongatapu in patterns not yet elucidated in full detail, although dated mid-Holocene coral was collected from an emergent paleoreef flat exposed by excavations in downtown Nuku'alofa only a kilometer from Fanga'Uta Lagoon (Taylor 1978); and (3) wave action has locally built beach ridges and spits along Holocene shorelines favorably situated to receive calcareous sand from sources of detritus on expanding offshore reef flats to the north of the island (Roy 1990, 1997). Longshore drift of calcareous sand is dominantly westward along the northern coast of Tongatapu under the influence of surf driven by the prevailing trade winds.

Modification of last-interglacial paleoshoreline features has been too extensive to allow pre-Holocene positions of the Fanga 'Uta lagoonal shoreline to be specified closely, but the morphology of the mid-Holocene paleoshoreline is well preserved in many areas. Its position is marked for long reaches of its course by a distinct slope declivity, rising 2-4 $\mathrm{m}$ from coastal flats within a horizontal distance of $10-25 \mathrm{~m}$. The slope forms an abrupt break in local topography, with much flatter ground both above and below. Tephra cover over the interior of Tongatapu is characteristic of the surface behind the paleoshoreline, but is absent below the paleoshoreline declivity. Lapita sites are irregularly distributed with respect to modern geography, some near the coast and some well inland, but all lie close to the paleoshoreline trend. The shell middens and sherd scatters of a number of sites are perched atop or along the lip of the paleoshoreline declivity (Figure 1). The persistent occurrence of mid-Holocene paleoshoreline features encircling Fanga 'Uta Lagoon at the consistent elevation expected without tectonic deformation supports the inference of no significant Holocene uplift, subsidence, or tilting of Tongatapu.

The surface of Lapita-age "paleo-Tongatapu" lying inland from the mid-Holocene paleoshoreline is composed of undulating topography mantled by a cover of weathered tephra, which thickens from east to west toward volcanic sources along the active Tongan island arc. The net tephra thickness varies from $5.5 \mathrm{~m}$ to $1.5 \mathrm{~m}$ on Tongatapu as a whole (Spenneman 1997), with the youngest tephra layer thinning eastward from 1.0 to $0.5 \mathrm{~m}$ on uplands surrounding Fanga 'Uta Lagoon (Cowie 1980).

Post-Lapita coastal flats are nestled along the present Fanga 'Uta lagoonal shoreline, extending inland to the base of the declivity marking the mid-Holocene paleoshoreline trend. This late Holocene "new ground", generally devoid of tephra cover, typically stands only a meter or less above the water level in mangrove swamps fringing Fanga 'Uta Lagoon, and is subject to widespread ponding of surface water during rainy periods. 


\section{Paleoshoreline trace}

The position of the mid-Holocene paleoshoreline (Figure 1) generally mimics but differs slightly from the location inferred by Spenneman (1988, 1997:Figs. 2e, 13 bottom), who positioned the paleoshoreline at the 2-m contour on available topographic maps. The paleoshoreline was plotted during this study by tracing on the ground the slope declivity marking its trend. The position of the paleoshoreline was established within narrow lateral limits wherever the slope declivity is transected by streets and roads (approximately 60 localities), or lies along accessible village waterfronts, with its position between those intersections and shorefronts sketched by eye in the field.

In a few areas, the mapped paleoshoreline departs significantly from positions anticipated from contours shown on available topographic maps. These departures from expectation seemingly imply topographic discordances along the paleoshoreline trend. In my judgment, however, the apparent discordances do not record any tectonic deformation of the paleoshoreline, but instead reflect minor inaccuracies in the placement of contour lines drawn by photogrammetric methods across a landscape of low relief and variable tree height.

Westward from Nuku'alofa, the restriction of pottery finds to the topographic crest of a feature interpreted as a paleobeach ridge (Groube 1971:291-292) suggests that the Lapita-age paleoshoreline could be traced successfully near the north shore of Tongatapu well beyond the limits of the mapping undertaken around Fanga 'Uta Lagoon. In the Kolovai district of westernmost Tongatapu, however, an emergent lastinterglacial paleobeach ridge forms a prominent component of the island landscape (Lewis et al. 1997; Roy 1997), and might be misinterpreted as a mid-Holocene paleoshoreline feature.

\section{Paleoenvironmental relations}

The present-day Fanga 'Uta Lagoon, and especially its innermost arm west of the Fanga Kakau passage south of Nuku'alofa (Figure 1), is a severely restricted body of partly brackish water with a muddy bottom, limited shellfish fauna, and extensive fringing mangrove swamps. Even its eastern arm, leading directly to the landing place of Captain Cook near Mu'a in 1777, is screened by shoals that bridge the lagoon entrance, only $1.5 \mathrm{~km}$ wide between the lowlying island of Nukunukumotu and the Tongatapu mainland at Nukuleka (Figure 1).

In mid-Holocene time, extending at least until the initial Lapita occupation, the paleogeography of Fanga 'Uta Lagoon was qualitatively different. At present (Figure 2A), the Nuku' alofa peninsula forms a nearly continuous barrier across the mouths of both arms of Fanga 'Uta Lagoon. An additional screen of offshore reef islets further separates the modern Fanga 'Uta environment from open sea to the north. In Lapita time (Figure 2B), multiple passes between paleoislands then occupying the area of the present-day Nuku'alofa peninsula gave much more direct and extensive tidal access for ocean water into twin but separate Fanga 'Uta embayments (eastern and western). Both embayments were deeper and less landlocked than the two derivative arms of the presentday Fanga 'Uta Lagoon, into which the twin embayments evolved through post-mid-Holocene time. Shellfish middens at Lapita sites flanking Fanga 'Uta Lagoon are rich in marine genera that are sparse or absent in the modern Fanga 'Uta Lagoon, and point to a marked change in lagoonal ecology over time (Burley et al. 2001).

The trend of the principal island shoreline in Lapita time (Figure 2B) followed an arcuate course, slightly concave to the north, extending from Hofoa to the west of Nuku'alofa along a path near the southern shoreline of the present-day Fanga Kakau passage to the south of the present-day Nuku'alofa peninsula. This segment of the paleoshoreline lay directly along the northern edge of the Folaha peninsula between the two ancestral Fanga 'Uta embayments, and extended eastward beyond the mouth of the eastern embayment past 


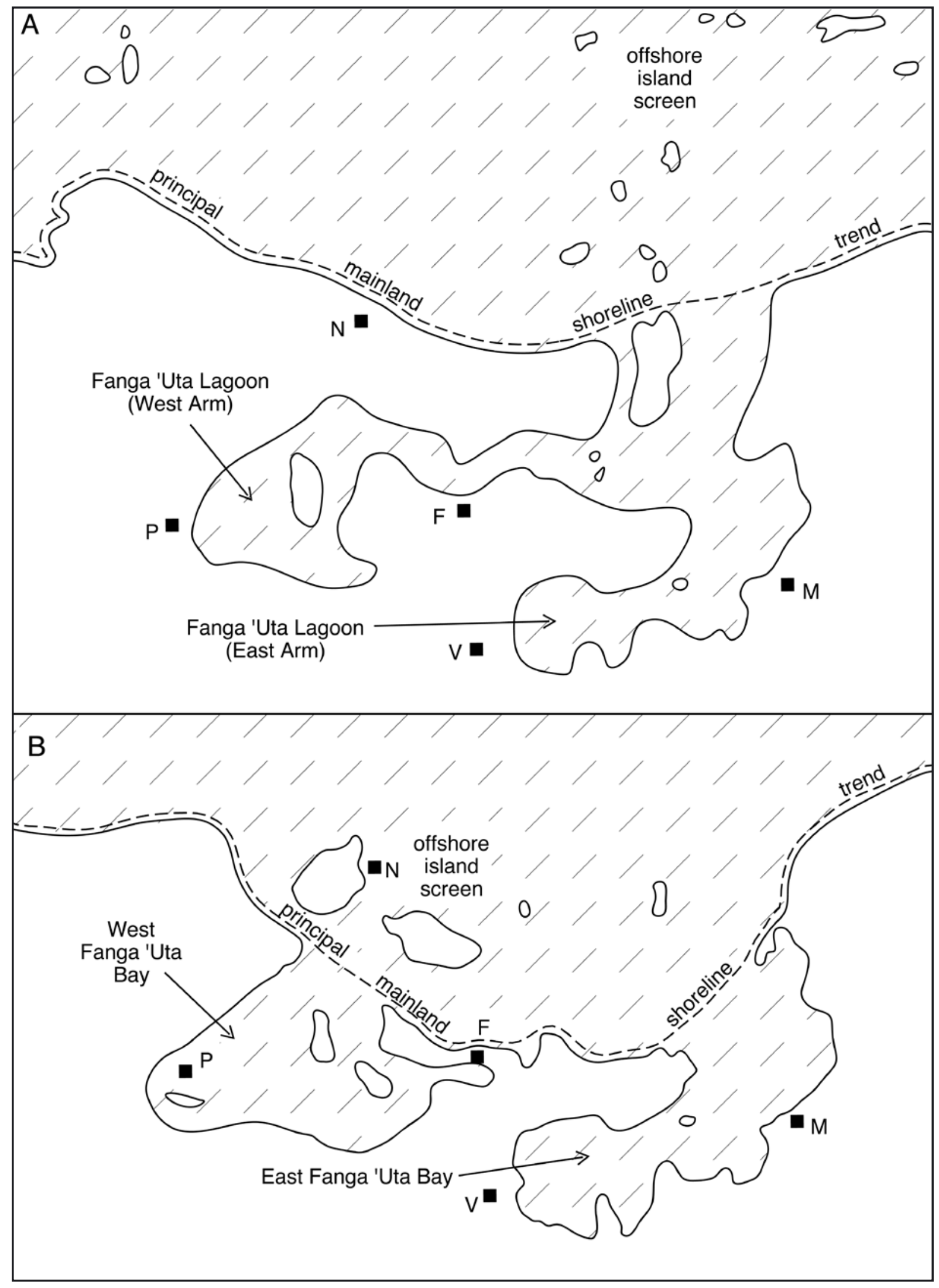

Figure 2. Modern (A) and Lapita (B) configurations (same scale) of the north coast of Tongatapu at Fanga 'Uta Lagoon (twin embayments at Lapita time) derived from Figure 1: F, Folaha; M, Mu'a; N, Nuku'alofa; P, Pea; V, Vaini. 
a prominent spit built at Nukuleka by longshore drift of beach sand. The beach sand was transported toward the southwest under the influence of the prevailing tradewinds from the coastline adjacent to more elevated tracts of northeastern Tongatapu. The heads of both the eastern and western Fanga 'Uta embayments lay no more than $5 \mathrm{~km}$ inland from comparatively open water north of the paleoshoreline trend.

In Lapita time, the site of modern Nuku'alofa was occupied in part by two small paleoislands nucleated around remnant Vaini patch reefs (Figure 1) that still form prominent hills on the urban landscape (including Brush Hill just west of the Royal Palace), but was otherwise drowned reef flat. The continuous barrier formed by the present-day Nuku'alofa peninsula did not yet exist. Sea water could pass from the open sea to the north directly across the site of modern Nuku' alofa into the western Fanga 'Uta embayment. Access from the eastern Fanga 'Uta embayment to the open sea was also closer and easier than today across a baymouth that was approximately $2 \mathrm{~km}$ wide between the Folaha peninsula and Nukuleka, and was located only $2 \mathrm{~km}$ offshore from Mu'a (Figure 2B). High ground near the northwestern tip of the Folaha peninsula, which separates the eastern and western arms of the present-day Fanga 'Uta Lagoon, was almost a separate island, linked to the main part of the peninsula to the southeast by a low swale rising only slightly above the mid-Holocene intertidal zone (Figure 1).

\section{Lapita Sites}

As indicated on the accompanying geoarchaeological map (Figure 1), a number of Lapita sites are distributed along the edge of Lapita-age "paleo-Tongatapu" at or just above the lip of the slope declivity marking the mid-Holocene paleoshoreline. Several sites lie southward from Nuku'alofa along the paleoshoreline trend west of Fanga 'Uta Lagoon and several others lie along the paleoshoreline trend within and near Mu'a east of Fanga 'Uta Lagoon. Two comparatively isolated sites occur along the paleoshoreline trend south of the west arm of Fanga 'Uta Lagoon and on the north side of the Folaha peninsula between the two arms of the lagoon, but their apparent isolation may be a function of limited archaeological surveying in areas distant from Nuku'alofa or Mu'a. Additional unsurveyed Lapita sites may well be present at intervals along the whole paleoshoreline trend.

Four known Lapita sites within the area of the present-day Nuku'alofa urban complex lay near the coasts of offshore paleoislands (Figure 1) that partially screened the western Fanga 'Uta embayment from the open sea (Figure 2B). Elsewhere within the Lapita region, Lapita settlements were commonly located on small islets offshore from larger landmasses (Lepofsky 1988). In two localities, known Lapita settlements stand at somewhat lower elevations with respect to modern sea level than the crest of the slope declivity along the mid-Holocene paleoshoreline, but their elevations are compatible with post-Lapita emergence of Tongatapu by 1.2-1.4 $\mathrm{m}$ (as inferred above):

(1) At Nukuleka north of $\mathrm{Mu}^{\prime} \mathrm{a}$, an excavated Lapita horizon near the southern limit of the modern village lies only 1.2-1.5 m above modern high-tide level. This Lapita settlement apparently occupied the extreme southern tip of a sandy spit (Figures 1-2) built part way across the mouth of the eastern of the twin Lapita-age Fanga 'Uta embayments as hydro-isostatic sea-level began to recede from the mid-Holocene highstand. As the oldest known Lapita site in Tonga (Burley and Dickinson 2001), Nukuleka may have been founded at the first dry land encountered at the entrance from the sea to the eastern and most open of the twin Lapita-age Fanga 'Uta embayments (Figure 2B). The Nukuleka spit is one of only two prominent Holocene spits built along the north shore of Tongatapu by westward longshore drift of reef-derived calcareous sand under the influence of the prevailing tradewinds. The other spit, initiated in post-Lapita time, extends westward from Nuku'alofa where its crest is marked by the course of the western segment of Vuna Road (Roy 1997). 
(2) Within a lowlying modern village complex near Pea at the southwestern corner of Fanga 'Uta Lagoon, two known Lapita horizons stand only 1.2-1.5 m above present water level in the adjacent lagoon. Both lie along the subdued crest of a low rise interpreted as the remnant of a paleoisland that formed as a slightly emergent sand cay constructed near the head of the western of the twin Lapita-age Fanga 'Uta embayments as hydroisostatic sea level began to recede from the mid-Holocene highstand. The paleocay stood well into the midHolocene embayment from well defined paleoshoreline declivities (to the west and south) that converge toward a poorly defined mid-Holocene bayhead southwest of the paleocay (Figure 1). Examination of the sediment beneath the paleocay suggests deposition within a shallow tidal lagoon (Crook 1987), implying formation of the paleocay by tidal currents within the shoaling bayhead environment.

The comparatively lowlying Lapita sites at Nukuleka and near Pea may not have provided as much protection from incursions by the sea during stormy periods as the Lapita sites at slightly higher elevations along the mid-Holocene paleoshoreline declivity, but were located on sandy paleobeaches where canoe landing may have been easier than anywhere else along the paleoshoreline of Fanga 'Uta Lagoon. The Lapita sites on small paleoislands now incorporated into the Nuku' alofa peninsula lie along inner paleocoasts at locales that would have been shielded to some extent from wave activity in the open sea to the north.

\section{Overall conclusions}

Lapita paleoenvironments near Fanga 'Uta Lagoon cannot be understood with the modern landscape as a reference guide. Paleoshoreline analysis of Fanga 'Uta Lagoon and its environs reveals a mid-Holocene paleogeography different in significant respects from the present-day environment. Not only did the Lapita-age shoreline lie well inland from the modern shoreline, but the two arms of Fanga 'Uta Lagoon were embayments harboring deeper water, with less restricted access to the open sea north of Tongatapu. Lapita sites now set back at varying distances from the shoreline of the modern muddy lagoon fringed by mangrove swamps stood at the time of occupation atop the beaches of embayments or associated islets with ready access to abundant marine resources. From paleogeographic analysis, it seems likely that rich shellfish resources of the ancestral Lapita-age Fanga 'Uta embayments, coupled with attractive sheltered paleoshorelines lying along the fringes of the embayments and on associated offshore islets, may have attracted to Tongatapu one of the densest Lapita populations in the ancient Pacific world. The geoarchaeology and paleogeography of Fanga 'Uta Lagoon underscores the value of coordinated archaeological and geological investigations in Pacific Oceania.

\section{Acknowledgements}

The base map for Figure 1 was compiled from Sheets 21-22 of the 1975 topographic map (scale 1:25,000) of the Tongatapu Group prepared by the British Directorate of Overseas Surveys, and published for the Kingdom of Tonga by the British Ministry of Overseas Development. All locations of Lapita archaeological sites were plotted in company with David V. Burley (Archaeology Department, Simon Fraser University), who also pointed out to me the distinctive break in slope along the mid-Holocene paleoshoreline trend from Vaiola Hospital to Tufu Mahina (located between Nuku'alofa and Pea). Drivers Aki and Vaha of Tokomololo village provided expert and cheerful guidance among the streets and lanes of Nuku'alofa, and along the byways of multiple villages and intervening countryside flanking the various shores of Fanga 'Uta Lagoon. Patient directions and advice on road conditions from numerous Tongans met during 
the course of field work, together with gracious permission to enter selected off-road properties, were essential for completion of the mapping project. My investigations were part of the research project of David V. Burley approved by the Office of the Prime Minister of the Kingdom of Tonga, and pursued by gracious permission of His Majesty King Taufa'ahau IV. Funds provided by the Social Sciences and Humanities Research Council of Canada supported my field work in 1999.

\section{References}

Anderson, A., R. Roberts, W. Dickinson, G. Clark, D. Burley, A. de Biran, G. Hope and P. Nunn 2006. Times of sand: Sedimentary history and archaeology at the Sigatoka dunes, Fiji. Geoarchaeology 21:131-154.

Burley, D.V. 1998. Tongan archaeology and the Tongan past, 2850-150 B.P. Journal of World Prehistory 12:337-392.

Burley, D.V. and W.R. Dickinson 2001. Origin and significance of a founding settlement in Polynesia. National Academy of Sciences Proceedings 98:11829-11831.

Burley, D.V. D.E. Nelson and R. Shutler, Jr. 1999. A radiocarbon chronology for the Eastern Lapita frontier in Tonga. Archaeology in Oceania 34:59-70.

Burley, D.V., W.R. Dickinson, A. Barton and R. Shutler, Jr. 2001. Lapita on the periphery: New data on old problems in the Kingdom of Tonga. Archaeology in Oceania 36:89-104.

Chappell, J. 1983. Evidence for smoothly falling sea levels relative to north Queensland, Australia during the past 6,000 years. Nature 302:406-408.

Clark, J.T. and M.G. Michlovic 1996. An early settlement in the Polynesian homeland: Excavations at 'Aoa Valley, Tutuila Island, American Samoa. Journal of Field Archaeology 23:151-167.

Cowie, J.D. 1980. Soils from andesitic tephra and their variability, Tongatapu, Kingdom of Tonga. Australian Journal of Soil Research 18:273-284.

Crook, K.A.W. 1987. Analysis of soil samples from To.1. In J. Poulsen, Early Tongan Prehistory (Vol. I), p. 268. Canberra: Department of Prehistory, Australian National University, Terra Australis 12.

Dickinson, W.R. 2001. Paleoshoreline record of relative Holocene sea levels on Pacific islands. Earth-Science Reviews 55:191-234.

Dickinson, W.R. and R.C. Green 1998. Geoarchaeological context of Holocene subsidence at the ferry berth Lapita site, Mulifanua, Upolu, Samoa. Geoarchaeology 13:239-263.

Dickinson, W.R. and D.V. Burley 2007. Geoarchaeology of Tonga: Geotectonic and geomorphic controls. Geoarchaeology 22:231-261.

Dickinson, W.R., D.V. Burley, P.D. Nunn, A. Anderson, G. Hope, A. de biran, C. Burke and S. Matararaba 1998. Geomorphic and archaeological landscapes of the Sigatoka dune site, Viti Levu, Fiji: Interdisciplinary investigations. Asian Perspectives 37:1-31.

Dickinson, W.R., D.V. Burley and R. Shutler, Jr. 1999. Holocene paleoshoreline record in Tonga: Geomorphic features and archaeological implications. Journal of Coastal Research 15:682-700.

Ellison, J.C. 1989. Pollen analysis of mangrove sediments as a sea-level indicator: Assessment from Tongatapu, Tonga. Palaeogeography, Palaeoclimatology, Palaeoecology 74:327-341

Green, R.C. 2002. A retrospective view of settlement pattern studies in Samoa. In T.N. Ladefoged and M.W. Graves (eds), Pacific Landscapes: Archaeological Approaches, pp. 125-152. Los Osos, California: Easter Island Foundation.

Green, R.C. and D. Anson 2000. Archaeological investigations on Watom Island: Early work, outcomes of recent investigations, and future prospects. New Zealand Journal of Archaeology 20(1998): 183-197.

Groube, L.M. 1971. Tonga, Lapita pottery, and Polynesian origins. Journal of the Polynesian Society 80:278-316.

Harvey, N., E.J. Barnett, R.P. Bourman and A.P. Belperio 1999. Holocene sea-level change at Port Pirie, South Australia: A contribution to global sea-level rise estimates from tide gauges. Journal of Coastal Research 15:607-615. 
Israelson, C. and B. Wohlfarth 1999. Timing of the last-interglacial high sea level on the Seychelles Islands, Indian Ocean. Quaternary Research 51:306-316.

Kirch, P.V. 1988. Niuatoputapu, the Prehistory of a Polynesian Chiefdom. Seattle: Thomas Burke Memorial Washington State Museum Monograph 5.

Kirch, P.V. 1993. The To'aga site: Modelling the morphodynamics of the land-sea interface. In P.V. Kirch and T.L. Hunt (eds), The To'aga Site: Three Millenia of Polynesian Occupation in the Manu'a Islands, American Samoa, pp. 3142. Berkeley: Univerity of California Archaeological Research Facility Contribution No. 51.

Kirch, P.V., T.L. Hunt, L. Nagaoka and J. Tyler 1990. An ancestral Polynesian occupation site at To'aga, Ofu Island, American Samoa. Archaeology in Oceania 15:1-15.

Lepofsky, D. 1988. The environmental context of Lapita settlement locations. In P.V. Kirch and T.L. Hunt (eds), Archaeology of the Lapita Cultural Complex: A Critical Review, pp. 33-47. Seattle: Thomas Burke Memorial Washington State Museum Research Report No. 5.

Lewis, K.B., R.B. Smith and J.S. Pow 1997. Future sand supplies for Tongatapu, Kingdom of Tonga. In R. Howorth and P. Rodda (eds), Coastal and Environmental Geoscience Studies of the Southwest Pacific Islands, pp. 175-191. Suva: South Pacific Applied Geoscience Commission (SOPAC) Technical Bulletin 9.

Mitrovica, J.X. and G.A. Milne 2002. On the origin of late Holocene sea-level highstands within equatorial ocean basins. Quaternary Science Reviews 21: 2179-2190.

Mitrovica, J.X. and W.R. Peltier 1991. On postglacial geoid subsidence over the equatorial oceans: Journal of Geophysical Research 96:20052-20071.

Nunn, P.D. and F.T. Finau 1995. Holocene emergence of Tongatapu island, south Pacific. Zeitschrift für Geomorphologie 39:69-95.

Poulsen, J. 1987. Early Tongan Prehistory (Vol. I). Canberra: Department of Prehistory, Australian National University, Terra Australis 12.

Roy, P.S. 1990. The morphology and surface geology of Tongatapu and Vava'u, Kingdom of Tonga. Suva: South Pacific Applied Geoscience Commission (SOPAC) Technical Report 62.

Roy, P.S. 1997. The morphology and surface geology of the islands of Tongatapu and Vava'u, Kingdom of Tonga. In R. Howorth and P. Rodda (eds.), Coastal and Environmental Geoscience Studies of the Southwest Pacific Islands, pp. 153-173. Suva: South Pacific Applied Geoscience Commission (SOPAC) Technical Bulletin 9.

Spenneman, D.H. 1988. Pathways to the Tongan past. Nuku'alofa: Tonga Government Printer.

Spenneman, D.H. 1997. A Holocene sea-level history for Tongatapu, Kingdom of Tonga. In R. Howorth and P. Rodda (eds.), Coastal and Environmental Geoscience Studies of the Southwest Pacific Islands, pp. 115-151. Suva: South Pacific Applied Geoscience Commission (SOPAC) Technical Bulletin 9.

Taylor, F.W., Jr. 1978. Quaternary Tectonic and Sea-Level History, Tonga and Fiji, Southwest Pacific. PhD dissertation, Cornell University.

Taylor, F.W., Jr. and A.L. Bloom 1977. Coral reefs on tectonic blocks, Tonga island arc. Third International Coral Reef Symposium Proceedings (Miami) 2:275-281.

Torrence, R., C. Pavlides, P. Jackson and J. Webb 2000. Volcanic disasters and cultural discontinuities in Holocene time in West New Britain, Papua New Guinea. In W.G. McGuire, D.R. Griffiths, P.L. Hancock and I.S. Stewart (eds), The Archaeology of Geological Catastrophes, pp. 225-244. London: Geological Society Special Publication 171.

Woodroffe, C.D. 1988. Vertical movements of isolated oceanic islands at plate margins: Evidence from emergent reefs in Tonga (Pacific Ocean), Cayman Islands (Caribbean Sea), and Christmas Island (Indian Ocean). Zeitschrift für Geomorphologie Supplement-Band 69:17-37.

Woodroffe, C.D., D.M. Kennedy, D. Hopley, C.E. Rasmussen and S.G. Smithers 2001. Holocene reef growth in Torres Strait. Marine Geology 170:331-346. 